\title{
GROWTH OF JUVENILES OF THE FAT SNOOK, Centropomus parallelus, IN RESPONSE TO DIETARY LIPID, ENERGY AND PROTEIN
}

\section{Crescimento de jovens de robalo-peva, Centropomus parallelus, em resposta à dieta de lipídios, energia e proteína}

\author{
Ricardo Camurça Correia Pinto ${ }^{1,3}$, Alberto Jorge Pinto Nunes ${ }^{2,3}$ \\ ${ }^{1}$ Coordenador da Unidade de Pesquisa em Piscicultura Marinha (UPMAR). Universidade Federal do Ceará, \\ Instituto de Ciências do Mar, Fortaleza, Ceará, Brasil. E-mail: ricardo.camurca@ufc.br \\ ${ }^{2}$ Coordenador do Laboratório de Nutrição de Organismos Aquáticos (Lanoa) e professor associado \\ ${ }^{3}$ Universidade Federal do Ceará, Instituto de Ciências do Mar, Fortaleza, Ceará, Brasil. \\ Centro de Estudos Ambientais Costeiros (CEAC)
}

\begin{abstract}
This study evaluated the growth of fat snook Centropomus parallelus in response to the dietary total lipids, gross energy $(\mathrm{GE})$ and crude protein $(\mathrm{CP})$ content. In the $1^{\text {st }}$ experiment, five isonitrogenous diets with $541.7 \pm 2.4 \mathrm{~g} \mathrm{~kg}^{-1} \mathrm{CP}$ varied their lipid content in $113,151,160,189$ and $200 \mathrm{~g} \mathrm{~kg}^{-1}$ and GE in 18.8, 19.4, 20.4, 21.2 and $22.2 \mathrm{MJ} \mathrm{kg}^{-1}$, respectively. A total of 300 fish with $6.5 \pm 2.4 \mathrm{~g}$ were stocked in 30 tanks of $1 \mathrm{~m}^{3}$ under 10 fish m $\mathrm{m}^{-3}$ and reared for 96 days. There were no differences in fish final body weight $(38.2 \pm 12.5 \mathrm{~g})$, daily weight gain (DWG, $0.35 \pm 0.04 \mathrm{~g} \mathrm{day}^{-1}$ ) and specific growth rate (SGR, $1.92 \pm 0.11$ day $^{-1}$ ) among dietary treatments. Feed conversion ratio (FCR) was $1.76 \pm 0.17$ with a protein efficiency ratio of $1.06 \pm 0.10$. The viscerosomatic (VSI) and visceral fat indices (VFI) raised significantly with an increase in the dietary lipid while the hepatosomatic index (HSI) was unaffected. There was a significant reduction in feed intake as the dietary lipid content reached $189 \mathrm{~g} \mathrm{~kg}^{-1}$. In a $2^{\text {nd }}$ study, five isolipidic diets (114.4 $\pm 1.9 \mathrm{~g} \mathrm{~kg}^{-1}$ lipids) with decreasing levels of $\mathrm{CP}$ and GE of 578, 535, 505, 465, and $430 \mathrm{~g} \mathrm{~kg}^{-1}$ and 20.5, 19.9, 19.4, 18.9, and $18.1 \mathrm{MJ} \mathrm{kg}^{-1}$, respectively, were evaluated. A total of 1,450 fish of $5.8 \pm 2.1 \mathrm{~g}$ were reared in 30 tanks of $5.8 \mathrm{~m}^{3}$ under 10 fish $\mathrm{m}^{-3}$ for 93 days. Final survival reached $93.5 \pm 5.5 \%$. Fish DWG $\left(0.27 \pm 0.05 \mathrm{~g} \mathrm{day}^{-1}\right)$ and SGR $\left(1.78 \pm 0.11 \%\right.$ day $\left.^{-1}\right)$ did not vary in response to dietary CP. Final body weight significantly reduced while HSI increased in fish fed the $430 \mathrm{~g} \mathrm{~kg}^{-1}$ $\mathrm{CP}$ diet compared with fish fed the $578 \mathrm{~g} \mathrm{~kg}^{-1} \mathrm{CP}$ diet. Results of this work indicated that
\end{abstract}


fish between $5.8 \mathrm{~g}$ and $40.8 \mathrm{~g}$ wet body weight can maximize growth when fed diets containing $113.2 \mathrm{~g} \mathrm{~kg}^{-1}$ lipids, $540.5 \mathrm{~g} \mathrm{~kg}^{-1} \mathrm{CP}$ and a $34.7 \mathrm{MJ} \mathrm{kg}^{-1}$ energy to protein ratio.

Keywords: Centropomus parallelus, fat snook, protein, lipid, energy.

\section{RESUMO}

Este estudo avaliou o crescimento do robalo-peva Centropomus parallelus em resposta ao conteúdo dietético de lipídios totais, energia bruta (EB) e proteína bruta (PB). No primeiro experimento, cinco dietas isoproteicas com $541,7 \pm 2,4 \mathrm{~g} \mathrm{~kg}^{-1} \mathrm{~PB}$ variaram seus conteúdos de lipídios em 113, 151, 160, 189 e $200 \mathrm{~g} \mathrm{~kg}^{-1}$ e EB em 18,8; 19,4; 20,4; 21,2 e 22,2 $\mathrm{MJ} \mathrm{kg}^{-1}$ respectivamente. Um total de 300 peixes pesando 6,5 2,4 g foi distribuído em 30 tanques de $1 \mathrm{~m}^{3}$ numa densidade de estocagem de 10 peixes $m^{-3}$ e cultivado por 96 dias. Não houve diferenças significativas no peso corporal final $(38,2 \pm 12,5 \mathrm{~g})$, ganho de peso diário $\left(G P D, 0,35 \pm 0,04 \mathrm{~g}_{\text {day }}{ }^{-1}\right)$ e taxa de crescimento específico (TCE, 1,92 $\pm 0,11$ dia $^{-1}$ ) entre os tratamentos dietéticos. A taxa de conversão alimentar (TCA) foi de 1,76 0,17 com uma taxa de eficiência proteica de 1,06 0,10. O indice viscerossomático (IVS) e o indice de gordura visceral (IGV) aumentaram significativamente com o aumento do lipídio dietético, enquanto o índice hepatossomático (IHS) não foi afetado. Houve uma significativa redução no consumo alimentar dos peixes quando o conteúdo de lipídios nas dietas atingiu $189 \mathrm{~g} \mathrm{~kg}^{-1}$. No segundo estudo, cinco dietas isolipídicas $\left(114,4 \pm 1,9 \mathrm{~g} \mathrm{~kg}^{-1}\right.$ lipídios), com níveis decrescentes de PB e EB de 578, 535, 505, 465 e $430 \mathrm{~g} \mathrm{~kg}^{-1}$ e 20,5; 19,9; 19,4; 18,9 e 18,1 MJ kg-1 respectivamente, foram avaliadas. Um total de 1.450 peixes com 5,8 $\pm 2,1 \mathrm{~g}$ foi cultivado em 30 tanques de 5,8 $\mathrm{m}^{3}$ numa densidade de estocagem de 10 peixes $m^{-3}$ por 93 dias. A sobrevivência final alcançou 93,5 $\pm 5,5 \%$. $O$ GPD $\left(0.27 \pm 0.05 \mathrm{~g} \mathrm{day}^{-1}\right)$ e a TCE $\left(1,78 \pm 0,11 \%\right.$ dia $\left.{ }^{-1}\right)$ não variaram em resposta à $P B$ das dietas. O peso corporal final diminuiu significativamente, enquanto o IHS aumentou nos peixes alimentados com as dietas com $430 \mathrm{~g} \mathrm{~kg}^{-1}$ PB comparado com os peixes alimentados com as dietas contendo 578 $\mathrm{g} \mathrm{kg}^{-1} \mathrm{~PB}$. Os resultados deste trabalho indicaram que os peixes entre $5,8 \mathrm{~g}$ e 40, $8 \mathrm{~g}$ de peso corporal em base úmida podem maximizar seu crescimento quando alimentados com dietas contendo 113, $2 \mathrm{~g}$ $\mathrm{kg}^{-1}$ de lipídios, 540,5 $\mathrm{g} \mathrm{kg}^{-1} \mathrm{~PB}$ e com uma relação de energia/proteína de 34,7 MJ kg-1.

Keywords: Centropomus parallelus, robalo-peva, proteína, lipídio, energia.

\section{INTRODUCTION}

Snooks, also known as centropomids, are high valued tropical diadromous fish (Tucker, 1987; Cerqueira \& Tsuzuki, 2009), occurring strictly in the Eastern and Western coasts of the Americas (Rivas, 1986). These fish are popular in recreational fishing and by the quality of their white soft flesh (Tucker, 1985; Wallin et al., 1997). Snook aquaculture has been attempted for many years without success, although research on their reproductive aspects has been undertaken since the late 1970's (Shafland, 1979; Wallace et al., 1993; Taylor; Grier \& Whittington, 1998; Grier \& Taylor, 1998; Roberts et al., 1999; Neidig et al., 2000; Taylor et al., 2000; Tucker, 2003; Ibarra-Castro et al., 2011). In Brazil, spawning and hatchery techniques have been well established for the fat snook, Centropomus paralellus (Alvarez-Lajonchère et al., 2002; Cerqueira \& Tsuzuki, 2009) and under development for 
the common snook, Centropomus undecimallis (Soligo et al., 2008; Passini et al., 2014). Being a species dependent on estuaries, common snook are commonly found swimming in the water channel of marine shrimp farms in northeastern Brazil where they reach large size. Snook can be a good candidate for diversification of production in these facilities.

Many studies with common and fat snooks in Brazil have reported poor growth performance (Silva, 1976; Okada; Maia \& Rocha, 1980; Rocha \& Okada, 1980; Cavalheiro, 2000; Souza-Filho \& Cerqueira, 2003; Ostini et al., 2007; Tsuzuki; Cardoso \& Cerqueira, 2008; Silvão \& Nunes, 2017). However, growth rates as high as $1.5 \mathrm{~g} \mathrm{day}^{-1}$ for the common snook have been reported in other Latin American countries (Tucker, 1987; AlvarezLajonchère \& Tzusuki, 2008). Nevertheless, little information is available on their nutritional requirements (Seiffert; Cerqueira \& Madureira, 2001; Barroso et al., 2002; Lemos; Netto \& Germano, 2006; Tsuzuki \& Berestimas, 2008; Silvão \& Nunes, 2017).

The Asian sea bass or barramundi, Lates calcarifer, are also tropical catadromous and protandric hermaphroditic fish very similar to the American snooks (Guiguen et al., 1994; Alvarez-Lajonchère \& Tsuzuki, 2008). These two genera were considered phylogenetically close relatives in the past and part of the same family (Otero, 2004). Barramundi is an important aquaculture species in Southeast Asia and Australia. Most studies have found a dietary protein and lipid barramundi requirement from 450 to $550 \mathrm{~g} \mathrm{~kg}^{-1}$ and 140 to $190 \mathrm{~g} \mathrm{~kg}^{-1}$, respectively, varying with the dietary energy content and fish size (Glencross, 2006). In the light of these findings, we hypothesised that fat snook would grow better by increasing lipids and adjusting protein levels in their diets.

The identification of dietary levels of protein, lipids and energy are the starting point for the development of artificial diets that meet the nutritional requirements of a target species in aquaculture. Protein provides the essential amino acids while lipids contribute to the essential fat acids and energy needed for metabolic processes and species growth (NRC, 2011). Adequate content of lipids and energy can maximize the use of ingested protein for growth. Inversely, a diet with excessive energy leads to premature satiation and lower protein intake, ultimately restricting fish growth (NRC, 1993, Energy Requirements, pg. 5). Therefore, the proper ratio of energy to protein plays an important role in fish nutrition (Catacutan \& Coloso, 1995; Watanabe; Ellis \& Chaves, 2001; Williams et al., 2003).

The aquaculture of marine and diadromous carnivore fish is still dependent on fishmeal and fish oil as source of essential amino acids and n-3 series fat acids (Tacon \& Metian, 2008; Glencross et al., 2016). These ingredients are very expensive commodities, so the feed industry usually produces practical diets that also contain proteins and lipids from plant and land animal sources to reduce their costs.

Using this approach, the aim of this work was to make a preliminary investigation about the lipid, gross energy and crude protein levels of lab-extruded practical diets that better promote the growth of juveniles of the fat snook, C. parallelus.

\section{MATERIAL AND METHODS}

\section{Feeds and feeding}

This study was divided into two experiments. The $1^{\text {st }}$ evaluated the dietary lipid and energy levels, while the $2^{\text {nd }}$ the dietary protein content for maximum growth of fat snook. In the $1^{\text {st }}$ experiment, five isonitrogenous lab-extruded diets were prepared to contain 541.7 $\pm 2.4 \mathrm{~g} \mathrm{~kg}^{-1}$ of crude protein (CP) with the following lipid levels: 113, 151, 160, 189, and 
$200 \mathrm{~g} \mathrm{~kg}^{-1}$ and 18.8, 19.4, 20.4, 21.2 and 22.2 MJ of gross energy (GE) kg-1, respectively (Table I). Dietary lipid was increased by rising the inclusion of anchovy oil and lowering the inclusion of kaolin, the latter with no nutritional value. Fish were fed by hand broadcasting at 7:00, 11:00 and 16:00 h until apparent satiation. Feeding stopped when uneaten pellets were observed on the tank bottom. The initial feeding rate was determined as $10 \%$ of the stocked fish biomass (Tucker, 1998).

Table I - Ingredient and proximate composition of diets used in the $1^{\text {st }}$ experiment

\begin{tabular}{|c|c|c|c|c|c|}
\hline \multirow{2}{*}{ Ingredients } & \multicolumn{5}{|c|}{ Dietary lipid ${ }^{1 / C o m p o s i t i o n ~(~} \mathrm{g} \mathrm{kg}^{-1}$, wet basis) } \\
\hline & 113 & 151 & 160 & 189 & 200 \\
\hline Salmon meal $^{2}$ & 410.0 & 410.0 & 410.0 & 410.0 & 410.0 \\
\hline Soybean meal ${ }^{3}$ & 200.0 & 200.0 & 200.0 & 200.0 & 200.0 \\
\hline Poultry by-product meal ${ }^{4}$ & 120.0 & 120.0 & 120.0 & 120.0 & 120.0 \\
\hline Kaolin $^{5}$ & 100.4 & 80.0 & 59.5 & 39.1 & 18.7 \\
\hline Fish oil ${ }^{6}$ & 11.2 & 31.6 & 52.1 & 72.5 & 92.9 \\
\hline Soybean oil ${ }^{7}$ & 10.0 & 10.0 & 10.0 & 10.0 & 10.0 \\
\hline Wheat flour ${ }^{8}$ & 100.0 & 100.0 & 100.0 & 100.0 & 100.0 \\
\hline Mineral-vitamin premix ${ }^{9}$ & 20.0 & 20.0 & 20.0 & 20.0 & 20.0 \\
\hline Magnesium sulfate & 11.0 & 11.0 & 11.0 & 11.0 & 11.0 \\
\hline Monodicalcium phosphate ${ }^{10}$ & 7.0 & 7.0 & 7.0 & 7.0 & 7.0 \\
\hline Synthetic binder ${ }^{11}$ & 7.0 & 7.0 & 7.0 & 7.0 & 7.0 \\
\hline Potassium chloride & 3.0 & 3.0 & 3.0 & 3.0 & 3.0 \\
\hline Vitamin $C^{12}$ & 0.3 & 0.3 & 0.3 & 0.3 & 0.3 \\
\hline Ethoxyquin $^{13}$ & 0.1 & 0.1 & 0.1 & 0.1 & 0.1 \\
\hline \multicolumn{6}{|c|}{ Proximate composition ( $\mathrm{g} \mathrm{kg}^{-1}$, dry basis) } \\
\hline Moisture $^{14}$ & 94.7 & 103.1 & 110.8 & 113.7 & 111.1 \\
\hline Crude protein ${ }^{14}$ & 540.5 & 539.0 & 541.6 & 545.5 & 541.7 \\
\hline Crude lipid ${ }^{15}$ & 113.2 & 151.2 & 160.4 & 188.9 & 199.7 \\
\hline $\mathrm{Ash}^{14}$ & 212.0 & 191.1 & 171.1 & 153.0 & 134.2 \\
\hline Crude fiber ${ }^{14}$ & 17.0 & 17.5 & 18.2 & 14.0 & 15.5 \\
\hline Gross energy $^{14}\left(\mathrm{MJ} \mathrm{kg}^{-1}\right)$ & 18.8 & 19.4 & 20.4 & 21.2 & 22.2 \\
\hline Energy to protein ratio $\left(\mathrm{MJ} \mathrm{kg}^{-1}\right)$ & 34.7 & 36.0 & 37.6 & 38.9 & 40.9 \\
\hline
\end{tabular}

${ }^{1} 113$, diet with $113.2 \mathrm{~g} \mathrm{~kg}^{-1}$ total lipid (TL, dry matter basis); 151, diet with $151.2 \mathrm{~g} \mathrm{~kg}^{-1} \mathrm{TL} ; 160$, diet with $160.4 \mathrm{~g} \mathrm{~kg}^{-1} \mathrm{TL} ; 189$, diet with $188.9 \mathrm{~g} \mathrm{~kg}^{-1} \mathrm{TL}$; and 200, diet with $199.7 \mathrm{~g} \mathrm{~kg}^{-1} \mathrm{TL}$.

${ }^{2}$ Salmon meal, Pesquera Pacific Star S.A. (Puerto Montt, Chile). $739.1 \mathrm{~g} \mathrm{~kg}^{-1}$ crude protein $\left(\mathrm{CP}, 122.6 \mathrm{~g} \mathrm{~kg}^{-1} \mathrm{TL}, 156.7 \mathrm{~g} \mathrm{~kg}^{-1}\right.$ ash, $8.5 \mathrm{~g} \mathrm{~kg}^{-1}$ crude fiber (CF).

${ }^{3}$ Soybean meal 48\%. Bunge Alimentos S.A. (Luis Eduardo Magalhães, Brazil). $455.8 \mathrm{~g} \mathrm{~kg}^{-1} \mathrm{CP}, 22.8 \mathrm{~g} \mathrm{~kg}^{-1} \mathrm{TL}, 61.5 \mathrm{~g} \mathrm{~kg}^{-1} \mathrm{ash}_{\text {, }}$ $56.7 \mathrm{~g} \mathrm{~kg}^{-1} \mathrm{CF}$.

${ }^{4}$ NORDAL Nordeste Ind. de Derivados Animais Ltda. (Maracanaú, CE, Brazil). $615.5 \mathrm{~g} \mathrm{~kg}^{-1} \mathrm{CP}, 177.8 \mathrm{~g} \mathrm{~kg}^{-1} \mathrm{TL}, 64.2 \mathrm{~g} \mathrm{~kg}^{-1}$ ash, $8.4 \mathrm{~g} \mathrm{~kg}^{-1} \mathrm{CF}$.

${ }^{5}$ Caolim, Barra Beneficiamento de Minérios Ltda. (Soledade, Brazil). $985.0 \mathrm{~g} \mathrm{~kg}^{-1}$ ash.

${ }^{6}$ COPEINCA Corporación Pesquera INCA S.A. (Lima, Peru). $980.0 \mathrm{~g} \mathrm{~kg}^{-1} \mathrm{TL}$.

${ }^{7}$ Soybean oil, Bunge Alimentos S.A. (Gaspar, Brazil). $980.0 \mathrm{~g} \mathrm{~kg}^{-1} \mathrm{TL}$.

${ }^{8}$ Rosa Branca, Moinhos Cruzeiro do Sul S.A. (Olinda, Brazil). $119.5 \mathrm{~g} \mathrm{~kg}^{-1} \mathrm{CP}, 30.1 \mathrm{~g} \mathrm{~kg}^{-1} \mathrm{TL}, 5.8 \mathrm{~g} \mathrm{~kg}^{-1} \mathrm{ash}, 0.5 \mathrm{~g} \mathrm{~kg}^{-1} \mathrm{CF}$.

${ }^{9}$ Rovimix Camarão Extensivo, DSM Produtos Nutricionais Brasil Ltda. (São Paulo, SP). Guarantee level per kilogram of product: vitamin A, 1,000,000 IU; vitamin D3, 300,000 IU; vitamin E, 15,000 IU; vitamin K3, 300 mg; vitamin B1, 3,000 mg; vitamin B2, 2,500 mg; vitamin B6, 3,500 mg; vitamin B12, $6.0 \mathrm{mg}$; nicotinic acid, 10,000 mg; pantothenic acid, 5,000 mg; biotin, $100 \mathrm{mg}$; folic acid, $800 \mathrm{mg}$; vitamin C, 25,000 mg; choline, 40,000 mg; inositol, 20,000 mg; iron 2,000 mg; cupper, 3,500 mg; chelated cupper, 1,500 mg; zinc, 10,500 mg; chelated zinc, 4,500 mg; manganese, 4,000 mg; selenium, $15.0 \mathrm{mg}$; chelated selenium, 15 $\mathrm{mg}$; iodine, $150 \mathrm{mg}$; cobalt, $30 \mathrm{mg}$; chromium, $80 \mathrm{mg}$; filler, $1,000.0 \mathrm{~g}$.

${ }^{10}$ Fosfato 20 Monobicálcico, Serrana Nutrição Animal (Cajataí, SP, Brazil).

${ }^{11}$ Pegabind ${ }^{\mathrm{TM}}$, Bentoli Agrinutrition Inc. (Austin, USA). Synthetic binder based on urea formaldehyde.

${ }^{12}$ Rovimix Stay-C ${ }^{\circledast} 35 \%$, DSM Produtos Nutricionais Brasil Ltda. (São Paulo, Brazil). L-ascorbic acid-2-monophosphate, $\mathrm{Na}_{2} \mathrm{Ca}_{0.5} \mathrm{C}_{6} \mathrm{H}_{6} \mathrm{O}_{9} \mathrm{P}$.

${ }^{13}$ Ethoxiquin (poder), 66.6\%, Impextraco (Curitiba, Brazil).

${ }^{14}$ Analyzed (CBO Análises Laboratoriais, Campinas, Brazil).

${ }^{15}$ Analyzed (LABPRIMOR Laboratório de Análises Bromatológicas, Jaguaré, Brazil). 
In the $2^{\text {nd }}$ experiment, five diets were manufactured isolipidic $\left(114.4 \pm 1.9 \mathrm{~g} \mathrm{~kg}^{-1}\right)$ with decreasing levels of CP and GE, as follows: 578, 535, 505, 465, and $430 \mathrm{~g} \mathrm{~kg}^{-1}$; and, 20.5, 19.9, 19.4, 18.9, and $18.1 \mathrm{MJ} \mathrm{kg}^{-1}$, respectively (Table II). The reduction in dietary CP was achieved by lowering the dietary inclusion of salmon meal and raising the use of wheat flour and kaolin. Fat snook juveniles were trained to feed from $300 \mathrm{~mm}^{2}$ feeding trays, kept $60 \mathrm{~cm}$ suspended from the tank bottom. Meals were offered at 7:00 and 16:00 h. Uneaten pellets were recovered one hour before the next feed delivery and weighed. With this data, the next ration was determined by increasing $10 \%$ when no feed remains were found in the tray. On the contrary, feed ration was kept unchanged. All feed remains of each dietary treatment were oven-dried at $105^{\circ} \mathrm{C}$ for $72 \mathrm{~h}$ and weighed to determine fish feed intake on a dry-matter basis.

Table II - Ingredient and proximate composition of the diets used in the $2^{\text {nd }}$ experiment

\begin{tabular}{|c|c|c|c|c|c|}
\hline \multirow{2}{*}{ Ingredients } & \multicolumn{5}{|c|}{ Dietary crude protein ${ }^{1} /$ Composition $\left(\mathrm{g} \mathrm{kg}^{-1}\right.$, as is) } \\
\hline & 430 & 465 & 505 & 535 & 578 \\
\hline Salmon meal ${ }^{2}$ & 331.5 & 382.7 & 433.9 & 488.4 & 539.5 \\
\hline Soybean meal ${ }^{2}$ & 200.0 & 200.0 & 200.0 & 200.0 & 200.0 \\
\hline Brazilian fish meal $^{3}$ & 100.0 & 100.0 & 100.0 & 100.0 & 100.0 \\
\hline Kaolin ${ }^{2}$ & 107.3 & 77.3 & 47.4 & 30.2 & 0.0 \\
\hline Wheat flour ${ }^{2}$ & 150.0 & 134.0 & 118.0 & 86.0 & 70.3 \\
\hline Fish oil ${ }^{2}$ & 52.8 & 47.6 & 42.3 & 37.0 & 31.8 \\
\hline Soybean oil ${ }^{2}$ & 10.0 & 10.0 & 10.0 & 10.0 & 10.0 \\
\hline Mineral-vitamin premix ${ }^{2}$ & 20.0 & 20.0 & 20.0 & 20.0 & 20.0 \\
\hline Magnesium sulfate & 11.0 & 11.0 & 11.0 & 11.0 & 11.0 \\
\hline Monodicalcium phosphate ${ }^{2}$ & 7.0 & 7.0 & 7.0 & 7.0 & 7.0 \\
\hline Synthetic binder ${ }^{2}$ & 7.0 & 7.0 & 7.0 & 7.0 & 7.0 \\
\hline Potassium chloride & 3.0 & 3.0 & 3.0 & 3.0 & 3.0 \\
\hline Vitamin $C^{2}$ & 0.3 & 0.3 & 0.3 & 0.3 & 0.3 \\
\hline Ethoxyquin ${ }^{2}$ & 0.1 & 0.1 & 0.1 & 0.1 & 0.1 \\
\hline \multicolumn{6}{|c|}{ Proximate composition ( $\mathrm{g} \mathrm{kg}^{-1}$, dry basis) } \\
\hline Moisture $^{4}$ & 109.0 & 108.9 & 106.4 & 119.0 & 120.7 \\
\hline Crude protein ${ }^{4}$ & 429.5 & 465.3 & 505.1 & 535.2 & 577.7 \\
\hline Crude lipid ${ }^{5}$ & 114.8 & 117.0 & 111.9 & 114.2 & 113.8 \\
\hline $\mathrm{Ash}^{4}$ & 235.7 & 218.4 & 193.5 & 189.8 & 169.8 \\
\hline Crude fiber ${ }^{4}$ & 31.5 & 35.5 & 30.7 & 36.8 & 33.8 \\
\hline Nitrogen free extract ${ }^{6}$ & 188.4 & 163.8 & 158.8 & 124.1 & 104.9 \\
\hline Gross energy $^{6}\left(\mathrm{MJ} \mathrm{kg}^{-1}\right)$ & 18.1 & 18.9 & 19.4 & 19.9 & 20.5 \\
\hline Energy to protein ratio $\left(\mathrm{MJ} \mathrm{kg}^{-1}\right)$ & 42.2 & 40.6 & 38.4 & 37.1 & 35.5 \\
\hline
\end{tabular}

${ }^{1}$ 430, diet with $429.5 \mathrm{~g} \mathrm{~kg}^{-1}$ crude protein (CP, dry matter basis); 465, diet with $465.3 \mathrm{~g} \mathrm{~kg}^{-1} \mathrm{CP}$; 505 , diet with $505.1 \mathrm{~g} \mathrm{~kg}^{-1} \mathrm{CP}$; 535 , diet with $535.2 \mathrm{~g} \mathrm{~kg}^{-1} \mathrm{CP} ; 578$, diet with $577.7 \mathrm{~g} \mathrm{~kg}^{-1} \mathrm{CP}$.

${ }^{2}$ For details, see Table I.

${ }^{3}$ Courtesy of InVivo Nutrição e Saúde Animal Ltda. (Paulínia, Brazil). 516.5 g kg-1 CP; $149.5 \mathrm{~g} \mathrm{~kg}^{-1}$ total lipids (TL), $183.7 \mathrm{~g}$ $\mathrm{kg}^{-1}$ ash, $54.7 \mathrm{~g} \mathrm{~kg}^{-1}$ crude fiber (CF).

${ }^{4}$ Analyzed (CBO Análises Laboratoriais, Campinas, Brazil).

${ }^{5}$ Analyzed (LABPRIMOR Laboratório de Análises Bromatológicas, Jaguaré, Brazil).

${ }^{6}$ Calculated $(\mathrm{NFE}=1,000-\mathrm{CP}-\mathrm{CF}-$ ash $-\mathrm{CF})$.

In the present work, all diets were formulated to meet the essential fatty acids requirements of the Asian sea bass or barramundi L. calcarifer, the closest fat snook relative (Otero, 2004) which this information is known. Diets were formulated using the linear formulation software Feedsoft ${ }^{\circledR}$ Professional version 3.14 (Feedsoft Corporation, Richardson, Texas, EUA). Dietary levels of CP and GE followed reported values for barramundi, L. calcarifer (Boonyaratpalin, 1997; Williams \& Barlow, 1999; Glencross, 2006). Essential amino acid levels were also formulated to meet required levels suggested for the 
barramundi by Millamena (1994), Coloso et al. (1993) and Catacutan and Coloso (1995, 1997). A minimum of $10 \mathrm{~g} \mathrm{~kg}^{-1}$ of all dietary omega-3 (n-3) fatty acid was adopted in accordance to Boonyaratpalin (1997) and Wanakowat, Boonyaratpalin and Watanabe (1993). Dietary linolenic (C18:3n-3), eicosapentaenoic (C20:5n-3) and docosahexaenoic (C22:6n-3) acids followed recommendations by Williams and Barlow (1999) for barramundi. In regards to the dietary levels of calcium, magnesium, potassium, sodium, total phosphorus and chlorine, we followed the requirements reported for the rainbow trout, Oncorhynchus mykiss (NRC, 1993).

\section{Fish, experimental design and water quality}

Fat snook juveniles were purchased from the commercial hatchery Maricultura Pandini Ltda. (São Mateus, Espírito Santo, Brazil). Sand-filtered seawater was pumped from the Pacoti river estuary during high tides. Fresh water was used to adjust the salinity to less than $35 \mathrm{~g} \mathrm{~L}^{-1}$ whenever required. Acclimation period of fish was carried out in accordance to Silvão and Nunes (2017).

In the $1^{\text {st }}$ experiment, a total of 300 juvenile fish weighing $6.5 \pm 2.4 \mathrm{~g}$ were stocked in 30 cylindrical-conic polyethylene tanks of $1 \mathrm{~m}^{3}$ allowing five replicates. Fish were stocked under 10 animals $\mathrm{m}^{-3}$ and reared for 96 days. Water was exchanged at $30 \%$ of the total tank volume per day. Dissolved oxygen (DO) remained above $90 \%$ saturation. Mean water salinity, $\mathrm{pH}$ and temperature reached $35 \pm 2 \mathrm{~g} \mathrm{~L}^{-1}(n=2,490), 8.6 \pm 0.2(n=2,489)$, and 30.7 $\pm 0.7^{\circ} \mathrm{C}(n=2,490)$, respectively.

In the $2^{\text {nd }}$ experiment, 1,450 fish of $5.8 \pm 2.1 \mathrm{~g}$ body weight were stocked under 10 fish $\mathrm{m}^{-3}$ in 25 round tanks of $5.8 \mathrm{~m}^{3}$ made of polyvinyl chloride (PVC) sailcloth. Animals were reared for 93 days. Five replicate tanks were assigned for each dietary treatment. A total of $25 \%$ of the rearing water in each tank was exchanged twice a week. Mean water salinity, $\mathrm{pH}$ and temperature reached $30 \pm 2 \mathrm{~g} \mathrm{~L}^{-1}(n=1,625), 7.7 \pm 0.2(n=1,625)$, and $26.9 \pm 0.64^{\circ} \mathrm{C}$ $(n=1,623)$, respectively. Mean DO was $6.33 \pm 0.26 \mathrm{mg} \mathrm{L}^{-1}(n=1,624)$.

In both experiments, the ammonia and nitrite content was within the tolerable limits for the species.

\section{Fish weight and somatic indices}

In the $1^{\text {st }}$ experiment, five weight checks were carried out at fish stocking and harvest, and in days $24,48,72$ of rearing. In the $2^{\text {nd }}$ experiment, fish weight was checked only at stocking and at harvest, i.e., after 92 days of rearing. Fish weight and total length were determined by first anesthetizing animals in water mixed with clove oil (at $10 \%$ in ethylic alcohol, $4 \mathrm{~mL}$ solution diluted in $10 \mathrm{~L}$ of water). At harvest, three and four fish from each tank in the $1^{\text {st }}$ and $2^{\text {nd }}$ experiments, respectively, were sampled to determine somatic indices. Sampled fish had their viscera, liver and visceral fat dissected and weighed. Values were expressed as the percentage of their whole-body weight to calculate the viscerossomatic (VSI), hepatossomatic (HIS), and visceral fat indices (VFI), respectively.

\section{Growth parameters and statistics}

Fish survival (\%) was calculated by dividing the number of fish at harvest by the number of fish stored and multiplying by 100 . Fish specific growth rate (SGR, $\%$ day $^{-1}$ ) was calculated by the equation: $S G R=\left[\left(\ln _{\mathrm{f}}-\ln \mathrm{W}_{\mathrm{i}}\right) \div \mathrm{t}\right] \times 100$, in which $\mathrm{W}_{\mathrm{i}}=$ fish wet body 
weight $(\mathrm{g})$ at stocking, $\mathrm{W}_{\mathrm{f}}=$ fish wet body weight $(\mathrm{g})$ at harvest, and $\mathrm{t}=$ days of culture. Daily weight gain $\left(\mathrm{DWG}, \mathrm{g}\right.$ day $\left.^{-1}\right)$ was determined by the formula: $\mathrm{DWG}=[(\mathrm{Wf}-\mathrm{Wi}) \div \mathrm{t}]$. Percent weight gain $(\mathrm{PWG}, \%)$ was calculated as $\mathrm{PWG}=[(\mathrm{Wf} \div \mathrm{Wi})-1)] \times 100$. Feed conversion ratio (FCR) was calculated by dividing the apparent fish feed intake (AFI, $\mathrm{g}$, dry basis) by the wet fish biomass gained (g). Protein efficiency ratio (PER) was calculated by dividing fish biomass gained at harvest by the product of dietary $\mathrm{CP} \times \sum \mathrm{AFI}$.

The statistical package SPSS 15.0 for Windows (SPSS Inc., Chicago, Illinois, USA) was used in all statistical analyses. Fish growth performance and somatic parameters were analyzed through one-way ANOVA at a significance level of 5\%. Tukey's HSD test was used to compare the significant differences between the means when detected. Regression analysis equation was chosen using as criteria the maximum $\mathrm{R}$ square among the significant models of curve estimation. Quadratic regression analysis was used to estimate the minimum levels of dietary lipid and energy to protein ratio that resulted in a maximum fish weight gain.

\section{RESULTS}

In the $1^{\text {st }}$ experiment, fish growth performance showed no statistical difference when fed diets with varying lipid levels (Table III). Mean ( \pm standard deviation) final body weight, daily weight gain (DWG), and specific growth rate (SGR) reached 38.2 $\pm 12.5 \mathrm{~g}, 0.35$ $\pm 0.04 \mathrm{~g}$, and, $1.92 \pm 0.11 \%$ day $^{-1}$, respectively. Fish survival was $100 \%$ in all dietary treatments. Apparent feed intake (AFI) significantly reduced when dietary lipid increased. On the other hand, food conversion ratio (FCR, $1.76 \pm 0.17)$ and protein efficiency ratio $(P E R, 1.06 \pm 0.10)$ did not vary significantly in response to dietary lipid levels $(P>0.05)$. Fish viscerossomatic (VSI) and the visceral fat indices (VFI) significantly increased when total lipid content was raised above $160 \mathrm{~g} \mathrm{~kg}^{-1}$ of the diet, while hepatossomatic index (HSI) remained unchanged in all treatments $(P>0.05$; Table IV). Quadratic regression analysis were significant (Figures 1 and 3) but the inflexion points estimated were out of the sample space for both lipid and E:P ratio, although very close to the lower dietary lipid inclusion (113.2 $\mathrm{g} \mathrm{kg}^{-1}$ diet).

Table III - Experiment 1. Growth performance parameters of fat snook juveniles Centropomus parallelus fed diets with raising levels of lipids and energy for 92 days

\begin{tabular}{cccccccc}
\hline \multirow{2}{*}{$\begin{array}{c}\text { Diets }^{2} \\
\left(\mathrm{~g} \mathrm{~kg}^{-1}\right)\end{array}$} & $\begin{array}{c}\text { Final BW } \\
(\mathrm{g}, \text { as is })\end{array}$ & $\begin{array}{c}\text { DWG } \\
\left(\mathrm{g} \mathrm{day}^{-1}\right)\end{array}$ & $\begin{array}{c}\text { PWG } \\
(\%)\end{array}$ & $\begin{array}{c}\text { SGR } \\
\left(\% \text { day }^{-1}\right)\end{array}$ & $\begin{array}{c}\text { AFI } \\
\left(\mathrm{g} \mathrm{fish}^{-1} \text { day }^{-1}\right)\end{array}$ & FCR & PER \\
\hline 113 & $40.8 \pm 12.6$ & $0.37 \pm 0.04$ & $524 \pm 53$ & $1.99 \pm 0.09$ & $0.65 \pm 0.26^{\mathrm{a}}$ & $1.73 \pm 0.11$ & $1.08 \pm 0.07$ \\
151 & $40.0 \pm 11.9$ & $0.37 \pm 0.05$ & $503 \pm 49$ & $1.95 \pm 0.09$ & $0.62 \pm 0.25^{\mathrm{ab}}$ & $1.72 \pm 0.16$ & $1.09 \pm 0.10$ \\
160 & $38.1 \pm 12.9$ & $0.35 \pm 0.05$ & $496 \pm 82$ & $1.93 \pm 0.16$ & $0.60 \pm 0.23^{\mathrm{bc}}$ & $1.74 \pm 0.22$ & $1.08 \pm 0.13$ \\
189 & $36.7 \pm 12.5$ & $0.33 \pm 0.04$ & $478 \pm 58$ & $1.90 \pm 0.11$ & $0.58 \pm 0.24^{\mathrm{c}}$ & $1.76 \pm 0.16$ & $1.05 \pm 0.09$ \\
200 & $35.2 \pm 12.2$ & $0.31 \pm 0.03$ & $447 \pm 40$ & $1.85 \pm 0.08$ & $0.59 \pm 0.23^{\mathrm{bc}}$ & $1.87 \pm 0.19$ & $1.00 \pm 0.10$ \\
\hline Mean \pm SD & $38.2 \pm 12.5$ & $0.35 \pm 0.04$ & $490 \pm 60$ & $1.92 \pm 0.11$ & -- & $1.76 \pm 0.17$ & $1.06 \pm 0.10$ \\
ANOVA $^{3} P$ & 0.086 & 0.108 & 0.238 & 0.248 & $<0.001$ & 0.515 & 0.515 \\
\hline
\end{tabular}

${ }^{1}$ Final BW, final body weight (g, as is); DWG, daily weight gain; PWG, percent weight gain, and SGR, specific growth rate; AFI, aparent feeding intake in $\mathrm{g} \mathrm{fish}^{-1}$ day $^{-1}, n=546 ; \mathrm{FCR}$, food conversion rate; PER, protein efficiency rate. Columns with same letters indicate statistical difference no significant among treatments at the level of $\alpha=0.05$ according to theTukey HSD a posteriori test.

${ }^{2}$ Dry basis: 113 , diet containing $113.2 \mathrm{~g} \mathrm{~kg}^{-1}$ total lipids (TL); 151, diet containing $151.2 \mathrm{~g} \mathrm{~kg}^{-1} \mathrm{TL}$; 160 , diet containing $160.4 \mathrm{~g}$ $\mathrm{kg}^{-1} \mathrm{TL} ; 189$, diet containing $188.9 \mathrm{~g} \mathrm{~kg}^{-1} \mathrm{TL}$; and, 200, diet containing $199.7 \mathrm{~g} \mathrm{~kg}^{-1} \mathrm{TL}$.

${ }^{3}$ The one-way analysis of variance (ANOVA). 
Table IV - Somatic indices (mean \pm standard deviation) of fat snook fed with increasing levels of dietary lipid and gross energy for 92 days

\begin{tabular}{lccc}
\hline $\begin{array}{l}\text { Diets }^{2} \\
\left(\mathrm{~g} \mathrm{~kg}^{-1}\right)\end{array}$ & \multicolumn{3}{c}{ Somatic indices $^{1}(\%)$} \\
\cline { 2 - 4 } 113 & VSI & HSI & VFI \\
151 & $8.3 \pm 1.5^{\mathrm{a}}$ & $1.3 \pm 0.2$ & $4.3 \pm 1.3^{\mathrm{a}}$ \\
160 & $9.0 \pm 1.3^{\mathrm{ab}}$ & $1.3 \pm 0.3$ & $4.9 \pm 1.3^{\mathrm{ab}}$ \\
189 & $9.4 \pm 1.2^{\mathrm{abc}}$ & $1.3 \pm 0.2$ & $5.4 \pm 1.2^{\mathrm{abc}}$ \\
200 & $10.2 \pm 1.3^{\mathrm{bc}}$ & $1.2 \pm 0.2$ & $5.9 \pm 1.3^{\mathrm{bc}}$ \\
\hline Mean \pm SD & $10.3 \pm 1.3^{\mathrm{c}}$ & $1.2 \pm 0.1$ & $6.1 \pm 1.2^{\mathrm{c}}$ \\
ANOVA $^{3} P$ & -- & $1.3 \pm 0.2$ & -- \\
\hline
\end{tabular}

${ }^{1}$ VSI, viscerossomatic index (\%), $n=93$; HSI, hepatossomatic index (\%), $n=93$; VFI, visceral fat index (\%), $n=87$.

${ }^{2} 113$, diet with $113.2 \mathrm{~g} \mathrm{~kg}^{-1}$ total lipid (TL, dry matter basis); 151, diet with $151.2 \mathrm{~g} \mathrm{~kg}^{-1} \mathrm{TL} ; 160$, diet with $160.4 \mathrm{~g} \mathrm{~kg}^{-1} \mathrm{TL} ; 189$, diet with $188.9 \mathrm{~g} \mathrm{~kg}^{-1} \mathrm{TL}$; and 200, diet with $199.7 \mathrm{~g} \mathrm{~kg}^{-1} \mathrm{TL}$.

${ }^{3}$ One-way analysis of variance. Columns with common letters indicate non-statistical differences at $\alpha=0.05$ according to Tukey's HSD.

Figure 1 - Quadratic regression curve showing the dispersion of percent weight gain points (\%) of fat snook (Centropomus parallelus) in response to the lipid content of the diet (\%, dry matter basis)

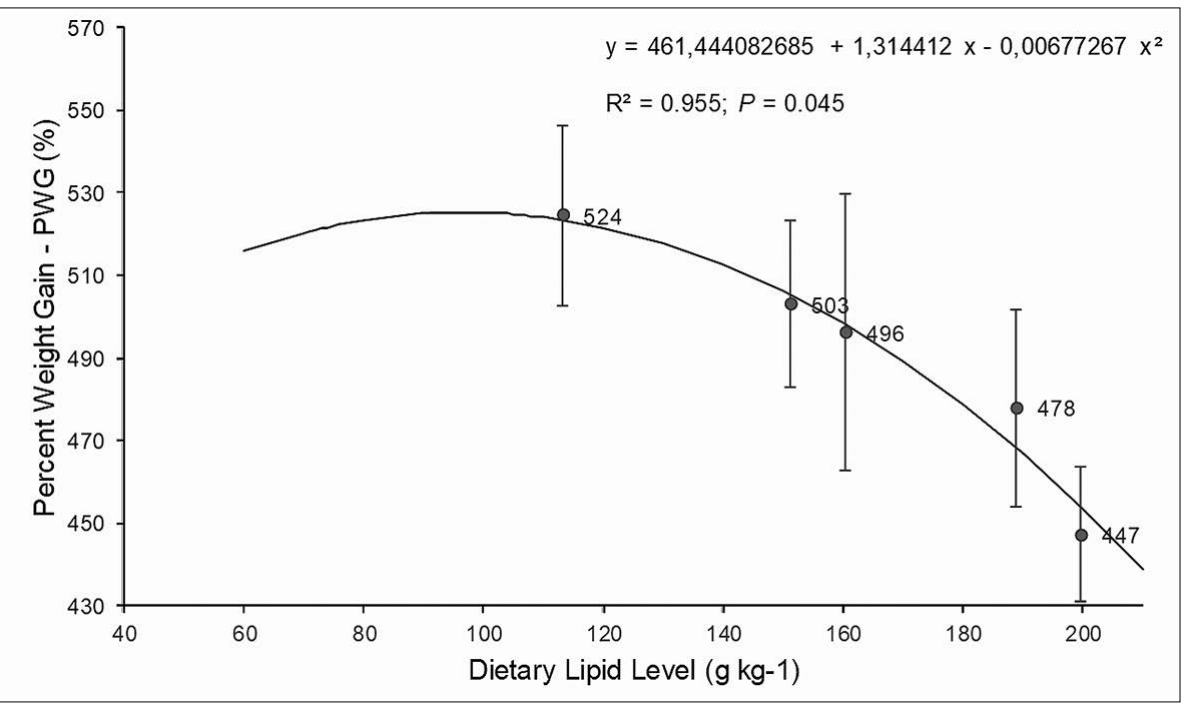

Figure 2 - Fat accumulation in the visceral cavity of fat snook Centropomus parallelus fed diets with dietary lipid inclusion beyond $160 \mathrm{~g} \mathrm{~kg}^{-1}$

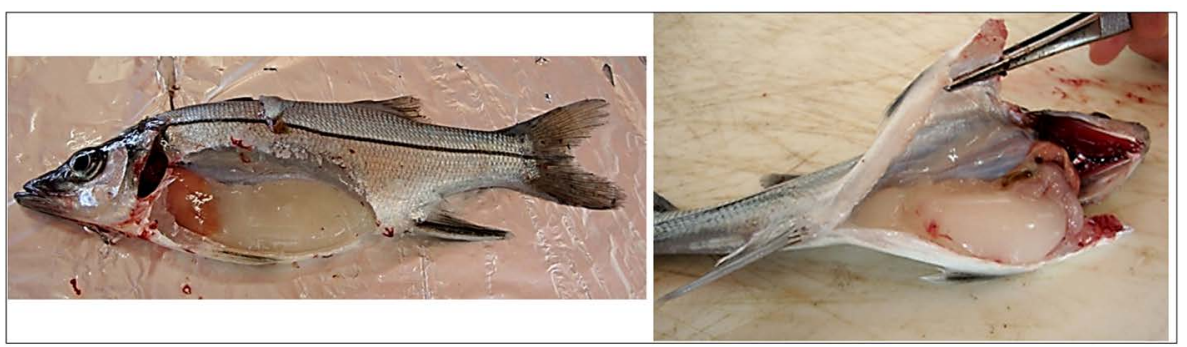


Figure 3 - Quadratic regression curve showing the dispersion of percent weight gain points (\%) of fat snook (Centropomus parallelus) in response to dietary Energy to Protein ratio (MJ g-1, dry matter basis)

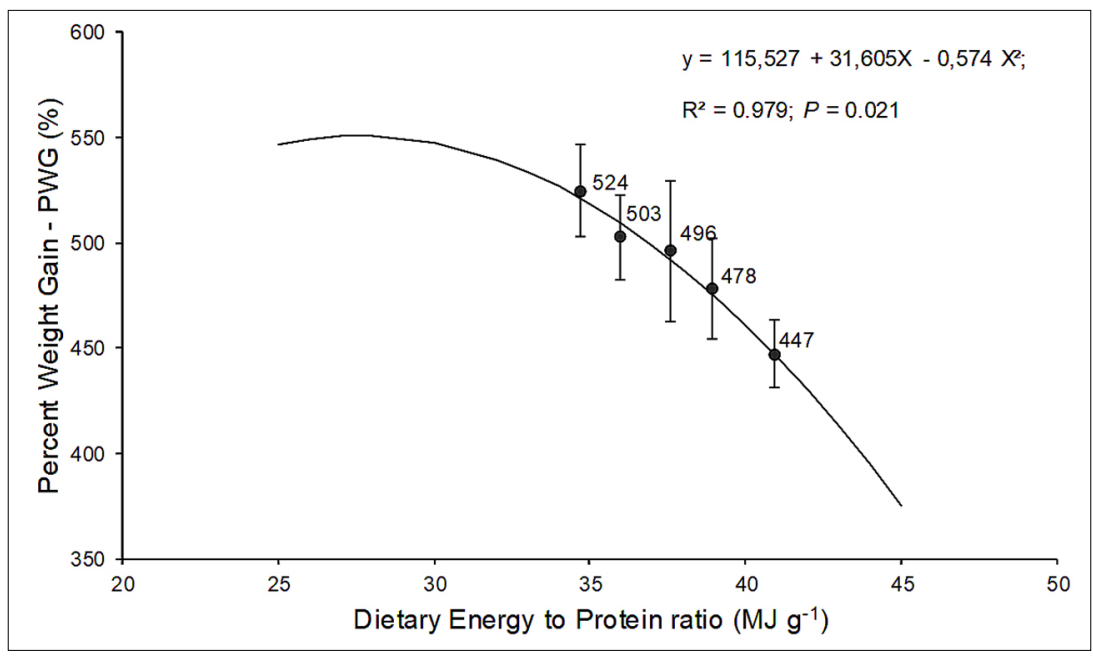

In the $2^{\text {nd }}$ experiment, fish survival reached of $93.5 \pm 5.5 \%$ and was unaffected by dietary treatment $(P>0.05)$. Final body weight of the fat snook fed diet with the highest $\mathrm{CP}$ content $\left(578 \mathrm{~g} \mathrm{~kg}^{-1}, 33.0 \pm 16.0 \mathrm{~g}\right)$ was significantly higher only when compared with the lowest protein level diet $\left(430 \mathrm{~g} \mathrm{~kg}^{-1}, 28.4 \pm 14.5 \mathrm{~g}\right.$, Table V). DWG $\left(0.27 \pm 0.05 \mathrm{~g} \mathrm{day}^{-1}\right)$, and SGR $\left(1.78 \pm 0.11 \%\right.$ day $\left.^{-1}\right)$ did not vary statistically among dietary treatments. Raising dietary protein did not affect AFI $(0.72 \pm 0.29), \operatorname{FCR}(2.51 \pm 1.09)$ or PER $(0.89 \pm 0.22)$. There were no differences in VSI and VFI among dietary treatments $(P>0.05)$. On the other hand, HSI significantly increased as dietary CP content reduced below $535 \mathrm{~g} \mathrm{~kg}^{-1}$ (Table VI). Curve estimation did not return any significant regression for fish weight gain in response to the protein level variation.

The best protein retention and the lowest lipid deposition were observed with fish fed the diets with the lowest lipid content $\left(540.5 \mathrm{~g} \mathrm{~kg}^{-1} \mathrm{CP}\right.$ and $113 \mathrm{~g} \mathrm{~kg}^{-1}$ lipids) in experiment 1. The protein diets of experiment 2 led to a lower protein retention and excessive deposition of lipid in fish body (Table VII).

Table V - Experiment 2. Growth performance parameters of fat snook juveniles Centropomus parallelus fed isolipidic diets $(114.4 \pm 1.9 \mathrm{~g} \mathrm{~kg}-1 \mathrm{TL})$ with raising levels of crude protein

\begin{tabular}{cccccccc}
\hline \multirow{2}{*}{$\begin{array}{c}\text { Diets }^{2} \\
\left(\mathrm{~g} \mathrm{~kg}^{-1}\right)\end{array}$} & $\begin{array}{c}\text { Final BW } \\
(\mathrm{g}, \text { as is })\end{array}$ & $\begin{array}{c}\text { DWG } \\
\left(\mathrm{g} \mathrm{day}^{-1}\right)\end{array}$ & $\begin{array}{c}\text { PWG } \\
(\%)\end{array}$ & $\begin{array}{c}\text { SGR } \\
\left(\% \text { day }^{-1}\right)\end{array}$ & $\begin{array}{c}\text { AFI } \\
\left(\mathrm{g} \mathrm{fish}^{-1} \text { day }^{-1}\right)\end{array}$ & FCR & PER \\
\hline $\mathbf{5 7 8}$ & $33.0 \pm 16.0^{\mathrm{a}}$ & $0.29 \pm 0.05$ & $448 \pm 69$ & $1.84 \pm 0.14$ & $0.79 \pm 0.34$ & $2.61 \pm 1.54$ & $0.80 \pm 0.33$ \\
$\mathbf{5 3 5}$ & $29.6 \pm 16.1^{\mathrm{ab}}$ & $0.26 \pm 0.07$ & $406 \pm 71$ & $1.75 \pm 0.16$ & $0.54 \pm 0.08$ & $1.93 \pm 0.26$ & $0.98 \pm 0.13$ \\
$\mathbf{5 0 5}$ & $30.7 \pm 16.7^{\mathrm{b}}$ & $0.27 \pm 0.04$ & $438 \pm 42$ & $1.83 \pm 0.08$ & $0.77 \pm 0.35$ & $2.61 \pm 1.28$ & $0.86 \pm 0.26$ \\
$\mathbf{4 6 5}$ & $29.5 \pm 15.2^{\mathrm{ab}}$ & $0.26 \pm 0.02$ & $413 \pm 20$ & $1.78 \pm 0.04$ & $0.84 \pm 0.42$ & $3.01 \pm 1.50$ & $0.82 \pm 0.26$ \\
$\mathbf{4 3 0}$ & $28.4 \pm 14.5^{\mathrm{b}}$ & $0.25 \pm 0.05$ & $376 \pm 40$ & $1.69 \pm 0.09$ & $0.64 \pm 0.08$ & $2.38 \pm 0.16$ & $0.98 \pm 0.07$ \\
\hline Mean \pm SD & --- & $0.27 \pm 0.05$ & $416 \pm 53$ & $1.78 \pm 0.11$ & $0.72 \pm 0.29$ & $2.51 \pm 1.09$ & $0.89 \pm 0.22$ \\
ANOVA $^{3} P$ & 0.032 & 0.724 & 0.328 & 0.323 & 0.524 & 0.661 & 0.624 \\
\hline
\end{tabular}

${ }^{1}$ Final BW, final body weight ( $\mathrm{g}$, as is); DWG, daily weight gain; PWG, percent weight gain, and SGR, specific growth rate; AFI, apparent feed intake; FCR, food conversion ratio; PER, protein efficiency ratio.

2578 , diet with $577.7 \mathrm{~g} \mathrm{~kg}^{-1} \mathrm{CP}$; 535, diet with $535.2 \mathrm{~g} \mathrm{~kg}^{-1} \mathrm{CP}$; 505, diet with $505.1 \mathrm{~g} \mathrm{~kg}^{-1} \mathrm{CP}$; 465, diet with $465.3 \mathrm{~g} \mathrm{~kg}^{-1} \mathrm{CP} ; 430$, diet with $429.5 \mathrm{~g} \mathrm{~kg}^{-1}$ crude protein (CP, dry matter basis).

${ }^{3}$ One-way analysis of variance. Columns with common letters indicate non-statistical differences at $\alpha=0.05$ according to Tukey's HSD. 
Table VI - Experiment 2. Somatic indexes (mean \pm standard deviation) of fat snook Centropomus parallelus fed diets with raising levels of crude protein for 92 days

\begin{tabular}{|c|c|c|c|}
\hline \multirow[b]{2}{*}{$\begin{array}{l}\text { Diets }^{2} \\
\left(\mathrm{~g} \mathrm{~kg}^{-1}\right)\end{array}$} & \multicolumn{3}{|c|}{ Somatic Indexes ${ }^{1}(\%)$} \\
\hline & VSI & HSI & VFI \\
\hline 578 & $8.17 \pm 1.02$ & $1.01 \pm 0.19^{\mathrm{a}}$ & $4.94 \pm 0.93$ \\
\hline 535 & $8.86 \pm 0.95$ & $1.17 \pm 0.15^{\mathrm{ab}}$ & $5.55 \pm 0.98$ \\
\hline 505 & $8.84 \pm 0.74$ & $1.23 \pm 0.21^{\mathrm{b}}$ & $5.43 \pm 0.83$ \\
\hline 465 & $8.87 \pm 0.85$ & $1.31 \pm 0.27^{\mathrm{b}}$ & $5.35 \pm 1.08$ \\
\hline 430 & $8.49 \pm 0.80$ & $1.22 \pm 0.19^{\mathrm{b}}$ & $5.22 \pm 0.88$ \\
\hline Mean \pm SD & $8.67 \pm 0.89$ & --- & $5.32 \pm 0.95$ \\
\hline $\mathrm{ANOVA}^{3} P$ & 0.078 & 0.001 & 0.395 \\
\hline
\end{tabular}

${ }^{1}$ VSI, viscerossomatic index $(\%), n=92$; HSI, hepatossomatic index (\%), $n=92$; VFI, visceral fat index $(\%), n=92$.

${ }^{2} 430$, diet with $429.5 \mathrm{~g} \mathrm{~kg}^{-1}$ crude protein (CP, dry matter basis); 465 , diet with $465.3 \mathrm{~g} \mathrm{~kg}^{-1} \mathrm{CP}$; 505, diet with $505.1 \mathrm{~g} \mathrm{~kg}^{-1} \mathrm{CP}$; 535 , diet with $535.2 \mathrm{~g} \mathrm{~kg}^{-1} \mathrm{CP} ; 578$, diet with $577.7 \mathrm{~g} \mathrm{~kg}^{-1} \mathrm{CP}$.

${ }^{3}$ One-way analysis of variance. Columns with common letters indicate non-statistical differences at $\alpha=0.05$ according to Tukey's HSD.

Table VII - Whole body composition analysis $\left(\mathrm{g} \mathrm{kg}^{-1}\right.$, on a dry matter basis) of fat snook fed diets with increasing levels of dietary lipid, gross energy, and crude protein (CP)

\begin{tabular}{cll|clc}
\hline $\begin{array}{c}\text { Dietary lipid } \\
\left(\mathrm{g} \mathrm{kg}^{-1}\right)\end{array}$ & $\begin{array}{l}\text { Body CP } \\
\left(\mathrm{g} \mathrm{kg}^{-1}\right)\end{array}$ & $\begin{array}{l}\text { Body lipid } \\
\left(\mathrm{g} \mathrm{kg}^{-1}\right)\end{array}$ & $\begin{array}{l}\text { Dietary protein }(\mathbf{C P} ; \\
\left.\mathrm{g} \mathrm{kg}^{-1}\right)\end{array}$ & $\begin{array}{l}\text { Body CP } \\
\left(\mathrm{g} \mathrm{kg}^{-1}\right)\end{array}$ & $\begin{array}{l}\text { Body lipid } \\
\left(\mathrm{g} \mathrm{kg}^{-1}\right)\end{array}$ \\
\hline Stocking & $\mathbf{7 5 0 . 4}$ & $\mathbf{9 6 . 3}$ & $\mathbf{4 3 0}$ & $\mathbf{6 6 6 . 3}$ & $\mathbf{9 6 . 3}$ \\
$\mathbf{1 1 3}$ & 747.2 & 124.3 & $\mathbf{4 6 5}$ & 672.9 & 234.5 \\
$\mathbf{1 5 1}$ & 747.0 & 149.5 & $\mathbf{5 0 5}$ & 661.1 & 241.4 \\
$\mathbf{1 6 0}$ & 704.8 & 181.0 & $\mathbf{5 3 5}$ & 667.1 & 235.5 \\
$\mathbf{1 8 9}$ & 732.3 & 145.0 & $\mathbf{5 7 8}$ & 685.8 & 231.6 \\
\hline $\mathbf{2 0 0}$ & 713.6 & 188.8 & & & \\
\hline
\end{tabular}

\section{DISCUSSION}

According to the NRC (2011; p. 106, Dietary Lipid Level, lines 35-37) "although an optimum dietary lipid level cannot be truly defined for any species, there is a range within which dietary lipid should be supplied". Results of this work indicate that juveniles of fat snook between 5.8 and $40.8 \mathrm{~g}$ can perform better when fed diets with a low lipid and a high crude protein content. Maximum fish growth was achieved with a diet containing $113.2 \mathrm{~g} \mathrm{~kg}^{-1}$ lipids, $540.5 \mathrm{~g} \mathrm{~kg}^{-1} \mathrm{CP}$ and an energy to protein (E:P) ratio of $34.7 \mathrm{MJ} \mathrm{kg}^{-1}$.

A deleterious effect on apparent feed intake (AFI) was observed when the dietary lipid level increased beyond $151 \mathrm{~g} \mathrm{~kg}^{-1}$. This was probably driven by a higher energy intake and a rapid energy satiation. An increasing lipid and energy intake has been related to suppress the appetite causing reduction in growth in several marine finfish (Marias \& Kissil, 1979; Williams \& Robinson, 1988; Ellis; Viala \& Watanabe, 1996; Watanabe; Ellis \& Chaves, 2001; NRC, 2011). In our study, a reduction in AFI did not affect protein efficiency ratio ( $\mathrm{PER}=$ fish biomass gain $\div \mathrm{CP} \times \mathrm{AFI})$ and $\mathrm{FCR}(=\mathrm{AFI} \div$ fish biomass gain). This indicated there was indeed a decrease in the gain of fish biomass as a result of a lower protein intake. 
The significant increase in VSI $(10.2 \pm 1.3 \%)$ and VFI (5.9 $\pm 1.3 \%)$ suggests there was a significantly higher fat deposition in the peritoneal cavity of juvenile fat snook as the dietary lipid content increased beyond $160 \mathrm{~g} \mathrm{~kg}^{-1}$ (Figure 2). Some marine and diadromous fish appear to have a metabolic threshold for an efficient lipid catabolism at higher dietary lipid levels (Watanabe; Ellis \& Chaves, 2001). The red snapper, Lutjanus analis (Watanabe; Ellis \& Chaves, 2001), and the Asian sea bass, Lates calcarifer (Williams et al., 2003) also showed an increased body fat deposition when fed with high dietary lipid levels. Conversely, the Atlantic salmon (Salmo salar) can utilize high dietary lipid concentrations to effectively spare protein for somatic growth (Karalazos; Bendiksen \& Bell, 2011). According to Williams et al. (2003) juveniles of the Asian sea bass show a limited ability to use lipid as a metabolic energy source unless diets are also provided with adequate levels of CP.

A well-balanced dietary energy to protein (E:P) ratio appears to be determinant for optimum growth in marine and diadromous fish. Catacutan and Coloso (1995) reported the Asian sea bass can be fed diets with a $32.7 \mathrm{MJ} \mathrm{kg}^{-1} \mathrm{E}: \mathrm{P}$ ratio (or a P:E of $128 \mathrm{mg} \mathrm{kcal}^{-1}$ ) without affecting their growth. Watanabe, Ellis and Chaves (2001) found higher growth in the red snapper, Lutjanus analis, fed diets with lower lipid levels $\left(60\right.$ and $\left.90 \mathrm{~g} \mathrm{~kg}^{-1}\right)$ and E:P ratios of 33,9 and $36,3 \mathrm{MJ} \mathrm{kg}^{-1}$, respectively. In agreement with these findings, the best growth of fat snook juveniles in our study was also achieved with the diet containing the lowest lipid level (113.2 $\left.\mathrm{g} \mathrm{kg}^{-1}\right)$ and an E:P ratio of $34.7 \mathrm{MJ} \mathrm{kg}$. This ratio increased as the lipid level raised in the diets. In addition, the regression curves of the lipids and the E:P ratio showed an inflection point to the left of the sample space (Figure 3), suggesting that lower levels of dietary lipids and the E:P ratio could be tested in future experiments. Once fish oil is one of the most expensive ingredients in fish diets, a low demand for the dietary inclusion of lipid favors snook aquaculture as this is aligned with sustainability.

It is reasonable to assume that any additional dietary lipid ingested would be used as energy, sparing dietary protein for fish growth. However, the fish growth reduced when the dietary lipids increased in the $1^{\text {st }}$ experiment. Carnivorous fish have an innate ability to catabolize protein for their energy needs (Tacon \& Cowey, 1985; NRC, 2011). Since diets had high protein content $\left(541.7 \pm 2.4 \mathrm{~g} \mathrm{~kg}^{-1}\right)$ in our study, it is possible that all dietary treatments had excess energy for fat snook. Unlike the voracious and swimming active barramundi (L. calcarifer), fat snook juveniles are hesitant during feeding. As these fish are categorized as opportunistic predators (Cerqueira \& Tsuzuki, 2009), it is unlikely that fat snook would invest too much energy on feeding or swimming. Although metabolic costs for maintenance in "lie-in-wait" predators may be reduced compared to other fishes (Tolley \& Torres, 2002), juveniles of fat snook (from 5.18 to $10.25 \mathrm{~g}$ ) fed live prawn showed a high metabolic demand (82\%; Lemos; Netto \& Germano, 2006). Therefore, it is likely that fat snook catabolizes protein for energy easily then lipids to meet their metabolic energy demand.

In our $2^{\text {nd }}$ experiment, we observed that a reduction in dietary $\mathrm{CP}$ did not significantly affect weight gain and SGR of fat snook juveniles with an initial body weight of $5.8 \mathrm{~g}$. Only the diet containing $430 \mathrm{~g} \mathrm{~kg}^{-1} \mathrm{CP}$ and a $42.2 \mathrm{MJ} \mathrm{kg}^{-1} \mathrm{E}: \mathrm{P}$ ratio significantly depressed final fish BW compared with the $578 \mathrm{~g} \mathrm{~kg}^{-1} \mathrm{CP}$ diet which contained an E:P ratio of 35,5 MJ kg-1. It is surprising that such a wide range of dietary $\mathrm{CP}$ has not led an even greater effect in fat snook growth. Garcia and Cerqueira (2000, apud Cerqueira \& Tsuzuki, 2009) reared earlylife stage fat snook juveniles $(0.21 \pm 0.02 \mathrm{~g})$ fed diets containing varying protein levels from 
430 to $570 \mathrm{~g} \mathrm{~kg}^{-1}$ for 90 days. Those authors also observed no significant differences in fish growth performance and concluded that a diet with $430 \mathrm{~g} \mathrm{~kg}^{-1} \mathrm{CP}$ with $42.7 \mathrm{MJ} \mathrm{kg}^{-1} \mathrm{E}: \mathrm{P}$ ratio (or a P:E ratio of $98 \mathrm{mg} \mathrm{kcal}^{-1}$ ) could be adopted in practical diets for fat snook earlylife stage juveniles. On the other hand, Tsuzuki and Berestimas (2008) found a better growth in fat snook juveniles weighing $4.1 \mathrm{~g}$ fed diets containing $450 \mathrm{~g} \mathrm{~kg}^{-1} \mathrm{CP}$ and only 70 $\mathrm{g} \mathrm{kg}^{-1}$ lipids when compared with a diet with $400 \mathrm{~g} \mathrm{~kg}^{-1} \mathrm{CP}$ and $100 \mathrm{~g} \mathrm{~kg}^{-1}$ lipids. We can infer that low dietary lipid level, together with the proper E:P ratio, were more relevant than the dietary crude protein $(\mathrm{CP})$ level for fat snook juveniles within the protein range evaluated in both experiments.

The best fat snook growth $(33.0 \pm 16 \mathrm{~g})$ in the $2^{\text {nd }}$ experiment of our study was achieved with the diet containing the higher protein level (578 $\mathrm{g} \mathrm{kg}^{-1} \mathrm{CP}$ ). Williams et al. (2003) worked with L. calcarifer fingerlings (80 g) fed diets varying CP from 438 to $647 \mathrm{~g} \mathrm{~kg}^{-1}$ and lipid at 130, 180, and $230 \mathrm{~g} \mathrm{~kg}^{-1}$. Fish achieved a higher growth when fed a diet containing $603 \mathrm{~g} \mathrm{~kg}^{-1} \mathrm{CP}, 180 \mathrm{~g} \mathrm{~kg}^{-1}$ lipid and a $39.8 \mathrm{MJ} \mathrm{kg}^{-1} \mathrm{E}: \mathrm{P}$ ratio, but not significantly different from the diet with $597 \mathrm{~g} \mathrm{~kg}^{-1} \mathrm{CP}, 130 \mathrm{~g} \mathrm{~kg}^{-1}$ lipid and a $35.1 \mathrm{MJ} \mathrm{kg}^{-1} \mathrm{E}: \mathrm{P}$ ratio, which is in line with our work. However, it may not be economically viable to produce practical diets containing more than $550 \mathrm{~g} \mathrm{~kg}^{-1}$ crude protein (Williams et al., 2003). The fish final BW (29.5 $\pm 15.2 \mathrm{~g}$ ) obtained with the $465 \mathrm{~g} \mathrm{CP} \mathrm{kg}^{-1}$ diet in our $2^{\text {nd }}$ experiment did not differ from the others for final weight and represents a lower cost than diets with higher protein. So, this $\mathrm{CP}$ level could be adopted for rearing fat snook juveniles. Nevertheless, fat snook growth was poorer with this diet when compared with the best diet of the $1^{\text {st }}$ experiment, therefore, the dietary CP level of $540.5 \mathrm{~g} \mathrm{~kg}^{-1}$ should be indicated for fat snook juveniles.

It is interesting to note that in Williams et al. (2003) study, the increase in dietary CP resulted in just a slight improvement in dietary nitrogen retention by the fish. According to the authors, the best protein retention occurred with the lowest lipid level $\left(70 \mathrm{~g} \mathrm{~kg}^{-1}\right)$. This corroborates with our results. The diet with the lowest dietary lipid content in our work (113.2 $\mathrm{g} \mathrm{kg}^{-1}$ lipid, $540.5 \mathrm{~g} \mathrm{~kg}^{-1} \mathrm{CP}$ and $34.7 \mathrm{E}: \mathrm{P}$ ratio) resulted in the highest protein $\left(747.2 \mathrm{~g} \mathrm{~kg}^{-1}\right)$ and lowest lipid $\left(124.3 \mathrm{~g} \mathrm{~kg}^{-1}\right)$ fish body retention. All diets with increasing levels of $\mathrm{CP}$ (430 to $578 \mathrm{~g} \mathrm{~kg}^{-1}$ ) resulted in a poor protein ( 666.3 to $685.8 \mathrm{~g} \mathrm{~kg}^{-1} \mathrm{CP}$, respectively) and an excessive lipid (235.2 to $231.6 \mathrm{~g} \mathrm{~kg}^{-1}$ lipids, respectively) fish body deposition. The best protein retention can be related to the lower E:P ratio in both cases, as suggested by regression analysis (Figure 3).

In diets with protein variation in the $2^{\text {nd }}$ experiment, the dietary fish meal inclusion decreased while soybean meal (SBM) remained unchanged, therefore, there was also a higher contribution of plant protein source in the diets with a reduction in their CP. According to Gatlin et al. (2007), concentrations of the 10 essential amino acids (EAA) and tyrosine are generally lower in SBM than in fish meal with the exception of cysteine. In addition, some antinutritional compounds present in SBM such as phytic acid hinder the availability of phosphorus and cationic minerals for the absorption of fish. On the other hand, the formulation program and mineral supplementation of diets in our work ensure compliance with nutritional requirements of fish. Besides, an inclusion of $100 \mathrm{~g} \mathrm{~kg}^{-1} \mathrm{of}$ national fish meal was kept to maintain a good amino acid profile in the diets. However, raffinose and stachyose carbohydrates present in SBM are not digestible for fish due to a lack of a-galactosidases that are necessary to metabolize these complex sugars (Gatlin et al., 2007). These antinutritional factors may have reduced the digestibility of diets and affected the results. 
Since in our $2^{\text {nd }}$ experiment all diets were isolipidic, there was no difference in VSI and VFI among dietary treatments. However, HSI progressively increased as the dietary $\mathrm{CP}$ level decreased being significantly higher below $535 \mathrm{~g} \mathrm{~kg}^{-1} \mathrm{CP}$. Although the dietary energy reduced from 20.5 to $18.1 \mathrm{MJ} \mathrm{kg}^{-1}$ as the dietary CP decreased, the dietary E:P ratio continuously raised. An increasing share of this energy was derived from carbohydrates, once there was an increase in the dietary inclusion of wheat flour usage and in dietary nitrogen free extract (NFE) to compensate the reduction in energy derived from the protein portion of the diets. Some studies showed that at low dietary lipid levels, an increase in carbohydrates lead to an increase in HSI. Catacutan and Coloso (1997) observed that an increase in the dietary inclusion of carbohydrate from 150 to $200 \mathrm{~g} \mathrm{~kg}^{-1}$ resulted in a significantly higher HSI in barramundi fed diets with low lipid level $\left(60 \mathrm{~g} \mathrm{~kg}^{-1}\right)$. Nonetheless, diets containing 120 and $180 \mathrm{~g} \mathrm{~kg}^{-1}$ lipid returned similar HSI regardless of their carbohydrate level. Nankervis, Mattheus and Appleford (2000) found significant higher HSI in L. calcarifer fed isonitrogenous diets $\left(525.2 \pm 6.7 \mathrm{~g} \mathrm{~kg}^{-1} \mathrm{CP}\right)$ with the highest energy content. Conversely, when the share of energy from dietary carbohydrate was high in relation to the energy share from dietary lipid, the diets containing high (21.5 MJ kg-1) and low (19.5 MJ kg-1) energy levels returned similar HSI. As in the present study, Webb, Rawlinson and Holt (2010) also observed an increase in HSI of cobia, Rachycentron canadum, fed diets with increasing E:P ratios at the cost of increasing dietary inclusion of carbohydrate. Diets were kept isonitrogenous $\left(435 \pm 11 \mathrm{~g} \mathrm{~kg}^{-1} \mathrm{CP}\right)$ and isolipidic $\left(64 \pm 1.9 \mathrm{~kg}^{-1} \mathrm{fat}\right)$ and had increased levels of dextrin (a carbohydrate source) to raise dietary energy content. In our study, it appears that at low dietary lipid levels and high carbohydrates inclusions, juveniles of fat snook stored energy from carbohydrates as fat on the liver as opposed to their peritoneal cavity. This stresses the importance of the proper dietary lipid inclusion and E:P ratio, as well as the species-specific metabolic limit for each nutrient.

\section{CONCLUSIONS}

Results of this work indicate that juveniles of fat snook between 5.8 and $40.8 \mathrm{~g}$ can perform better when fed diets with a low lipid and a high crude protein content. Fat snook at this stage of life can grow best when fed diets containing $113.2 \mathrm{~g} \mathrm{~kg}^{-1}$ lipids, $540.5 \mathrm{~g} \mathrm{~kg}^{-1}$ crude protein and a $34.7 \mathrm{MJ} \mathrm{kg}^{-1} \mathrm{E}: \mathrm{P}$ ratio (in a dry matter basis). Further research is needed to investigate the proper crude protein level in diets for fat snook juveniles, keeping dietary lipids marginally low, below the $113.2 \mathrm{~g} \mathrm{~kg}^{-1}$ threshold, and E:P ratio of the diets below 35

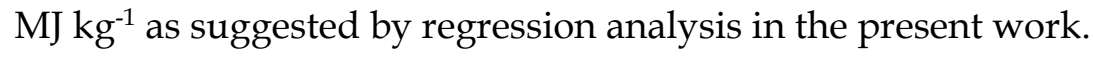

\section{REFERENCES}

Alvarez-Lajonchère, L.S.; Cerqueira, V.R.; Silva, I.D.; Araújo, J. \& Reis, M.A. Mass production of juveniles of the fat snook Centropomus parallelus in Brazil. Journal of the World Aquaculture Society, v. 33, p. 506-516, 2002.

Alvarez-Lajonchère, L. \& Tsuzuki, M.Y. A review of methods for Centropomus spp. (snooks) aquaculture and recommendations for the establishment of their culture in Latin America. Aquaculture Research, v. 39, p. 684-700, 2008. 
Barroso, M.V.; Castro, J.C.; Aoki, P.C.M. \& Helmer, J.L. Valor nutritivo de alguns ingredientes para o robalo (Centropomus parallelus). Revista Brasileira de Zootecnia, v. 31, p. 2157-2164, 2002.

Boonyaratpalin, M. Nutrient requirements of marine food fish cultured in Southeast Asia. Aquaculture, v. 151, p. 283-313, 1997.

Catacutan, M.R. \& Coloso, R.M. Effect of dietary protein to energy ratios on growth, survival, and body composition of juvenile Asian sea bass, Lates calcarifer. Aquaculture, v. 131, p. 125-133, 1995.

Catacutan, M.R. \& Coloso, R.M. Growth of juvenile Asian sea bass, Lates calcarifer, fed varying carbohydrate and lipid levels. Aquaculture, v. 149, p. 137-144, 1997.

Cavalheiro, J.M.O. Avaliação do desenvolvimento do camurim Centropomus parallelus (Poey, 1860) em água doce, submetido à alimentação artificial. Tese de doutorado, Programa de Pósgraduação em Ecologia e Recursos Naturais, Universidade Federal de São Carlos, 173 p., São Carlos, 2000.

Cerqueira, V.C. \& Tsuzuki, M.Y. A review of spawning induction, larviculture, and juvenile rearing of the fat snook, Centropomus parallelus. Fish Physiology and Biochemistry, v. 35, p. 17-28, 2009.

Coloso, R.M.; Murillo, D.P.; Borlongan, I.G. \& Catacutan, M.K. Requirement of juvenile sea bass Lates calcarifer Bloch, for tryptophan, in Program and Abstracts of the VI International Symposium on Fish Nutrition and Feeding, Hobart, Australia, October 4-7, 1993.

Ellis, S.C.; Viala, G. \& Watanabe, W.O. Growth and feed utilization of hatchery-reared juvenile Nassau grouper fed four practical diets. Progressive Fish-Culturist, v. 58, p. 168$173,1996$.

Gatlin III, D.M.; Barrows, F.T.; Brown, P.; Dabrowski, K.; Gaylord, T.G.; Hardy, R.W.; Herman, E.; HU, G.; Krogdahl, Å; Nelson, R.; Overturf, K.; Rust, M.; Sealey, W.; Skonberg, D.; Souza, E.J.; Stone, D.; Wilson, R. \& Wurtele, E. Expanding the utilization of sustainable plant products in aquafeeds: a review. Aquaculture Research, v. 38, p. 551-579, 2007.

Glencross, B. The nutritional management of barramundi, Lates calcarifer - a review. Aquaculture Nutrition, v. 12, p. 291-309, 2006.

Glencross, B.; Blyth, D.; Irvin, S.; Bourne, N.; Campet, M.; Boisot, P. \& Wade, N.M. An evaluation of the complete replacement of both fishmeal and fish oil in diets for juvenile Asian sea bass, Lates calcarifer. Aquaculture, v. 451, p. 298-309, 2016.

Grier, H.J. \& Taylor, R.G. Testicular maturation and regression in the common snook. Journal of Fish Biology, v. 53, p. 521-542, 1998.

Guiguen, Y.; Cauty, C.; Fostier, A.; Fuchs, J. \& Jalabert, B. Reproductive cycle and sex inversion of the sea bass, Lates calcarifer, reared in sea cages in French Polynesia: histological and morphometric description. Environmental Biology of Fishes, v. 39, p. 231-247, 1994.

Ibarra-Castro, L.; Alvarez-Lajonchère, L.; Rosas, C.; Palomino-Albarrán, I.G.; Holt, G.J. \& Sanchez-Zamora, A. GnRHa-induced spawning with natural fertilization and pilot-scale juvenile mass production of common snook, Centropomus undecimalis (Bloch, 1792). Aquaculture, v. 319, p. 479-483, 2011. 
Karalazos, V.; Bendiksen, E.Å. \& Bell, J.G. Interactive effects of dietary protein/lipid level and oil source on growth, feed utilisation and nutrient and fatty acid digestibility of Atlantic salmon. Aquaculture, v. 311, p. 193-200, 2011.

Lemos, D.; Netto, B. \& Germano, A. Energy budget of juvenile fat snook Centropomus parallelus fed live food. Comparative Biochemistry and Physiology, Part A, v.144, p. 33-40, 2006.

Marias, J.F.K. \& Kissil, G. Wm. The influence of energy level on the feed intake, growth, food conversion and body composition of Sparus aurata. Aquaculture, v. 17, p. 203-219, 1979.

Millamena, O.M. Review of SEAFDEC/AQD fish nutrition and feed development research, p. 52-63, in Santiago, C.B.; Coloso, R.M.; Millamena, O.M. \& Borlongan, I.G. (ed.). Feeds for Small-Scale Aquaculture, Proceedings of the National Seminar Workshop on Fish Nutrition and Feeds, SEAFDEC Aquaculture Department, Iloilo, Philippines, 1994.

Nankervis, L.; Matthews, S.J. \& Appleford, P. Effect of dietary non-protein energy source on growth, nutrient retention and circulating insulin-like growth factor I and triiodothyronine levels in juvenile barramundi, Lates calcarifer. Aquaculture, v. 191, p. 323335,2000 .

Neidig, C.L.; Skapura, D.P.; Grier, H.J. \& Dennis, C.W. Techniques for spawning common snook: broodstock handling, oocyte staging, and egg quality. North American Journal of Aquaculture, v. 62, p. 103-113, 2000.

NRC. National Research Council, 1993. Nutrient requirements of fish. Washington, D.C., USA: The National Academies Press, 124 p., 1993.

NRC. National Research Council, 2011. Nutrient requirements of fish and shrimp. Washington, D.C., USA: The National Academies Press, 376 p., 2011.

Okada, Y.; Maia, E.P. \& Rocha, I.P. Cultivo arraçoado de tainha (Mugil curema Valenciennes, 1836) em associação com robalo (Centropomus undecimalis Bloch, 1792) e carapeba (Eugerres brasilianus Cuvier, 1830), em viveiros estuarinos de Itamaracá-PE, p. 131-139, in Simpósio Brasileiro de Aquicultura, 1, 1978, Recife. Anais... Rio de Janeiro: Academia Brasileira de Ciências, 1980.

Ostini, S.; Oliveira, I.R.; Serralheiro, P.C.S. \& Sanches, E.G. Criação do robalo-peva (Centropomus parallelus) submetido a diferentes densidades de estocagem. Rev. Bras. Saúde Prod. An., v. 8, n. 3, p. 250-257, 2007.

Otero, O. Anatomy, systematics and phylogeny of both recent and fossil latid fishes (Teleostei, Perciformes, Latidae). Zoological Journal of the Linnean Society, v. 141, p. 81133, 2004.

Passini, G.; Carvalho, C.V.A.; Sterzelecki, F.C. \& Cerqueira, V.R. Induction of sex inversion in common snook (Centropomus undecimalis) males, using 17-b oestradiol implants. Aquaculture Research, p. 1-10, 2014.

Rivas, L.R. Systematic review of the Perciform fishes of the genus Centropomus. Copeia, p. 579-611, 1986.

Roberts, S.B.; Jackson, L.F.; King, V.W.; Taylor, R.G.; Grier, H.J. \& Sullivan, C. V. Annual reproductive cycle of the common snook: endocrine correlates of maturation. Transactions of the American Fisheries Society, v. 128, p. 436-445, 1999. 
Rocha, I.P. \& Okada, Y. Experimentos de policultivo entre curimã (Mugil brasiliensis Agassiz, 1829) e camorim (Centropomus undecimalis Bloch, 1792) em viveiros estuarinos (Itamaracá-Pernambuco), p. 163-173, in Simpósio Brasileiro de Aquicultura, 1, 1978, Recife. Anais... Rio de Janeiro: Academia Brasileira de Ciências, Brasil, 1980.

Seiffert, M.E.B.; Cerqueira, V.R. \& Madureira, L.A.S. Effect of dietary (n-3) highly unsaturated fatty acids on growth and survival of fat snook (Centropomus parallelus, Pisces: Centropomidae) larvae during first feeding. Brazilian Journal of Medical and Biological Research, v. 34, p. 645-651, 2001.

Shafland, P.L. Self-contained upwelling system for rearing larval fishes in the laboratory. The Progressive Fish-Culturist, v. 41, p. 10-13, 1979.

Silva, J.E. da. 1976. Fisioecologia do camorim (Centropomus undecimalis BLOCH, 1792): estudo experimental de crescimento em ambiente confinado. Tese de doutorado em Ciências e Fisiologia, Instituto de Biociências, Universidade de São Paulo, 101 p., São Paulo, 1976.

Silvão, C.F. \& Nunes, A.J.P. Effect of dietary amino acid composition from proteins alternative to fishmeal on the growth of juveniles of the common snook, Centropomus undecimalis. Revista Brasileira de Zootecnia, v. 46, n. 7, p. 569-575, 2017.

Soligo, T.A.; Ferraz E.M.; Cerqueira V.R. \& Tsuzuki, M.Y. Primeira experiência de indução hormonal, desova e larvicultura do robalo-flecha, Centropomus undecimalis, no Brasil, p. 143-152, in Cyrino, J.E.P.; Scorvo, F.J.D.; Sampaio, L.A. \& Cavalli, R. (ed.). Tópicos especiais em biologia aquática e aquicultura, v. 2. Jaboticabal, Brasil: Sociedade Brasileira de Aquicultura e Biologia Aquática, 2008.

Souza-Filho, J.J. \& Cerqueira, V.R. Influência da densidade de estocagem no cultivo de juvenis de robalo-flecha mantidos em laboratório. Pesquisa Agropecuária Brasileira, v. 38, p. 1317-1322, 2003.

Tacon, A.G.J. \& Cowey, B.C. Protein and amino acid requirements, p. 155-183, in Tyler, P. \& Calow, P. (ed.). Fish energetics: new perspectives. Baltimore, EUA: The Johns Hopkins University, 1985.

Tacon, A.G.J. \& Metian, M. Global overview on the use of fish meal and fish oil in industrially compounded aquafeeds: trends and future prospects. Aquaculture, v. 285, p. 146-158, 2008.

Taylor, R.G.; Grier, H.J. \& Whittington, J.A. Spawning rhythms of common snook in Florida. Journal of Fish Biology, v. 53, p. 502-520, 1998.

Taylor, R.G.; Whittington, J.A.; Grier, H.J. \& Crabtree, R.E. Age, growth, maturation, and protandric sex reversal in common snook, Centropomus undecimalis, from the east and west coasts of South Florida. Fishery Bulletin, v. 98, p. 612-624, 2000.

Tolley, S.G. \& Torres, J.J. Energetics of swimming in juvenile common snook, Centropomus undecimalis. Environmental Biology of Fishes, v. 63, p. 427-433, 2002.

Tsuzuki, M.Y. \& Berestinas, A.C. Desempenho de juvenis de robalo-peva Centropomus parallelus com diferentes dietas comerciais e freqüências alimentares. Boletim do Instituto de Pesca, v. 34, p. 535-541, 2008.

Tsuzuki, M.Y.; Cardoso, R.F. \& Cerqueira, V.R. Growth of juvenile fat snook Centropomus parallelus in cages at three stocking densities. Boletim do Instituto de Pesca, v. 34, p. 319-324, 2008. 
Tucker, J.W. Jr. Culinary value and composition of wild and captive common snook, Centropomus undecimalis. Florida Science, v. 48, p. 196-200, 1985.

Tucker, J.W. Jr. Snook and tarpon culture and preliminary evaluation for commercial farming. The Progressive Fish-Culturist, v. 49, p. 49-57, 1987.

Tucker, J.W. Jr. Marine fish culture. Boston, USA: Ed. Kluwer Academic Publishers, 731 p., 1998.

Tucker, J.W. Jr. Snook culture. World Aquaculture Magazine, v. 34, n. 4, p. 42-46, 2003.

Wallace, R.A.; Boyle, S.M.; Grief, H.J.; Selman, K. \& Petrino, T.R. Preliminary observations on oocyte maturation and other aspects of reproductive biology in captive female snook, Centropomus undecimalis. Aquaculture, v. 116, p. 257-273, 1993.

Wallin, J.E.; Ransier, J.M.; Fox, S. \& McMichael Jr., R.H. Short-term retention of coded wire and internal anchor tags in juvenile common snook, Centropomus undecimalis. Fishery Bulletin, v. 95, p. 873-878, 1997.

Wanakowat, J.; Boonyaratpalin, M. \& Watanabe, T. Essential fatty acid requirement of juvenile sea bass, p. 807-817, in Kaushik, S.J. \& Luquet, P. (ed.). Fish Nutrition in Practice, Paris, France, 1993.

Watanabe, W.O.; Ellis, S.C. \& Chaves, J. Effects of dietary lipid and energy to protein ratio on growth and feed utilization of juvenile mutton snapper Lutjanus analis fed isonitrogenous diets at two temperatures. Journal of World Aquaculture Society, v. 32, p. 30-40, 2001.

Webb Jr., K.A.; Rawlinson, L.T. \& Holt, G.J. Effect of dietary starches and the protein to energy ratio on growth and feed efficiency of juvenile cobia, Rachycentron canadum. Aquaculture Nutrition, v. 16, p. 447-456, 2010.

Williams, K.C. \& Barlow, C.G. Dietary requirement and optimal feeding practices for barramundi (Lates calcarifer): final report to Fisheries Research and Development Corporation, 95 p., Fish Meal Replacement Sub-Program, Project 92/63, Dept. of Primary Industries, Bribie Island, Qld, 1999.

Williams, K.C.; Barlow, C.G.; Rodgers, L.; Hockings, I.; Agcopra, C. \& Ruscoe, I. Asian sea bass Lates calcarifer perform well when fed pelleted diets high in protein and lipid. Aquaculture, v. 225, p. 191-206, 2003.

Williams, C.D. \& Robinson, E.H. Response of red drum to various dietary levels of menhaden oil. Aquaculture, v. 70, p. 107-120, 1988. 